\title{
STUDI VARIASI TEMPORAL DISTRIBUSI MASSA AIR MENGGUNAKAN DATA WATER THICKNESS SATELIT GRACE
}

\section{IIR IRAWATI, EKO YULI HANDOKO, IRA M. ANJASMARA}

\begin{abstract}
Program Studi Teknik Geomatika, Fakultas Teknik Sipil dan Perencanaan, Institut Teknologi Sepuluh November Kampus ITS Sukolilo, Surabaya, 60111, Indonesia
\end{abstract}

\begin{abstract}
Abstrak
GRACE (Gravity Recovery and Climate Experiment) merupakan hasil kerjasama antara National Aeronautics and Space Administration (NASA) di Amerika Serikat dan Deutsches Zentrum fur Luft-und Raumfahrt (DLR) di Jerman. Tujuan GRACE adalah untuk mengukur variasi medan gaya berat dengan akurasi sangat tinggi.

Dalam penelitian ini akan dilakukan proses analisa variasi distribusi massa air global. Penelitian ini menggunakan data hasil pengamatan GRACE selama 33 bulan antara Februari 2003 hingga April 2006, kecuali Januari dan Juni 2003, Januari 2004, serta Juli-Oktober 2004.

Hasil menunjukkan terdapat beberapa wilayah yang memiliki variasi distribusi massa air yang tinggi, yaitu Amerika Selatan, Amerika Utara, Afrika, Asia Selatan, dan Eropa Utara serta Timur. Nilai trend perubahan water thickness pada titik sampel adalah $2,71 \mathrm{~cm}, 1,61 \mathrm{~cm},-0,63 \mathrm{~cm},-1,25$ $\mathrm{cm}$, dan $1,37 \mathrm{~cm}$. Nilai trend perubahan water thickness pada titik sampel Indonesia adalah $-0,29$ $\mathrm{cm}$. Hasil plotting juga menunjukkan bahwa pola distribusi massa air global adalah sama setiap tahun.
\end{abstract}

Kata kunci : GRACE, distribusi massa air, water thickness

\section{PENDAHULUAN}

Perubahan medan gaya berat dihubungkan dengan perubahan massa pada dan di bawah permukaan bumi. Massa dan gaya berat berhubungan, peningkatan massa berhubungan dengan peningkatan gaya berat. Sebagian besar perubahan gaya berat dikaitkan dengan perubahan kandungan air, pergerakan laut, massa atmosfer, dan sebagainya. Karena komponen terbesar di bumi adalah air, yaitu $70 \%$ dari jumlah seluruh komponen bumi, maka perubahan pengamatan medan gaya berat bumi sebagian besar didomiasi oleh variasi kandungan air (Schmidt dan Schwintzer, 2006).

Pada penelitian ini dilakukan suatu analisa mengenai variasi temporal distribusi massa air berdasarkan data water thickness komponen Ocean dan Land water, yang selanjutnya akan turut mempengaruhi ketersediaan air. Water thickness diturunkan dari data gaya berat satelit GRACE dalam bentuk koefisien spherical harmonic. Karena perbedaan waktu sumber data untuk Ocean dan Land water mengakibatkan massa air tidak konstan dari waktu ke waktu dan dari posisi satu ke posisi lain, maka digunakan data water thickness masing-masing komponen dalam beberapa bulan untuk mengamati variasi temporal distribusi massa air global.

\section{SATELIT GRACE}

GRACE (Gravity Recovery and Climate Experiment) merupakan sistem satelit gravimetri hasil kerjasama antara NASA (National Aeronautics and Space 
Administration) di Amerika Serikat dengan DLR (Deutsches Zentrum für Luft-und Raumfahrt) di Jerman yang pengamatannya tidak menggunakan pantulan gelombang elektromagnetik, namun menggunakan pengukuran jarak dengan gelombang mikro untuk mendapatkan pengukuran teliti (Andreas, 2006). Satelit GRACE diluncurkan pada 17 Maret 2002 di Rusia.

Tujuan utama dari misi GRACE ini yaitu untuk menyediakan informasi yang cukup akurat dari model medan gaya berat bumi. Variasi medan gaya berat bumi dapat digunakan untuk mengamati pergerakan air global. GRACE adalah satu-satunya satelit NASA yang mampu mengamati semua tipe kandungan air. Tujuan lainnya dari misi GRACE yaitu menyediakan informasi mengenai besaran bias ionosfer dan troposfer yang dapat memperlambat dan melengkungkan sinyal pengukuran GPS (Global Positioning System). Alat yang dipasang pada satelit GRACE untuk penyediaan informasi ini berupa Lim Sounding. Alat ini dapat memberikan besaran TEC (Total Electron Content) dan atau refraktivitas dalam ionosfer dan troposfer (Andreas, 2006).

Teknik dari GRACE ini yaitu mendeteksi perubahan medan gaya berat bumi dengan cara memonitor perubahan jarak yang terjadi antara pasangan dua satelit GRACE pada orbitnya. Kedua satelit ini bergerak secara bersamasama pada track orbit dan terkoneksi oleh $K$ band microwave link untuk menghitung perbedaan jaraknya secara pasti, serta besarnya perubahan dengan akurasi lebih baik dari $1 \mu \mathrm{m} / \mathrm{s}$.

Penentuan posisi dan kecepatan satelit ditentukan dari sistem GPS yang ikut terpasang di kedua pasangan satelit GRACE.

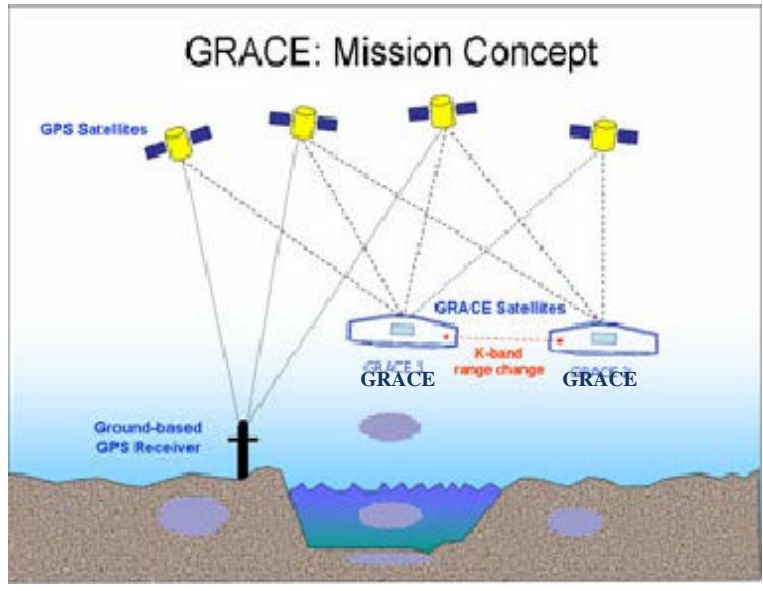

Gambar 1: Misi dari Satelit GRACE (Texas Advanced Computting Center, 2005)

\section{Pengukuran Gaya Berat dengan Satelit Grace}

GRACE memperoleh peta medan gaya berat melalui pengamatan bagaimana variasi massa bumi dari tempat satu ke tempat lain pada permukaan bumi. Karena kita ketahui bahwa massa dan gaya berat berkorelasi; peningkatan massa berhubungan dengan peningkatan gaya berat (Anjasmara, 2006).

Massa juga berhubungan dengan densitas dan jumlah material yang berada di beberapa tempat. Karena bumi mempunyai variasi bentuk topografi seperti gunung, lembah dan lorong-lorong, massa didistribusikan tidak sama di seluruh bumi dan bentuk fisik yang berbeda dapat dikenali. Dan yang diamati pada hasil medan gaya berat bumi berasal dari distribusi massa yang berubah-ubah pada permukaan bumi dan GRACE akan memetakan pertubasi ini (Anjasmara, 2006). 


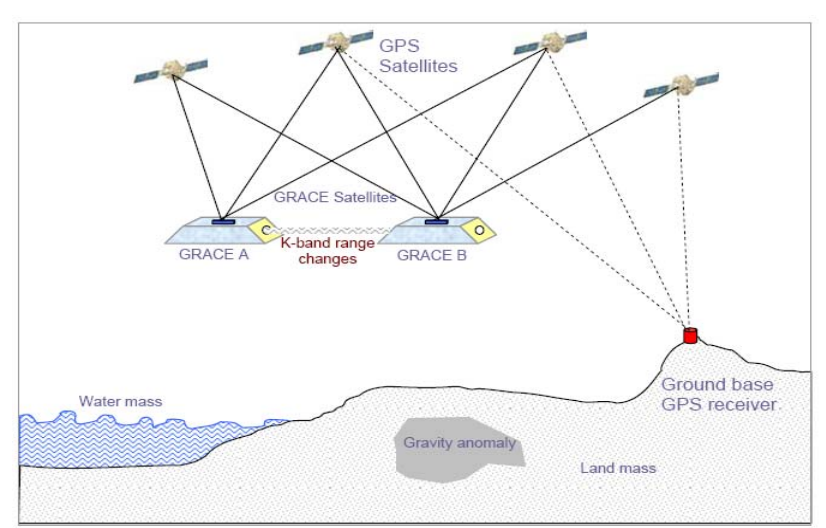

Gambar 2. Pengukuran Medan Gaya Berat oleh GRACE

Satelit GRACE mengukur anomali gaya berat dengan mengukur perubahan jarak antara kedua satelit. Jarak ini diukur dengan menggunakan $K$-Band microwave Ranging System yang sangat teliti. Karena kedua satelit mengorbit terhadap seluruh bumi, maka kecepatan yang teliti dari masing-masing satelit dan jarak antara keduanya secara konstan dihubungkan dengan instrumen microwave $K$-Band Ranging. Karena gaya berat berubah di bawah satelit yang berkorelasi terhadap perubahan massa di bawah permukaan bumi, maka jarak keduanya berubah.

\section{Data Water Thickness Satelit GRACE}

Proses data, distribusi, penyimpanan dan verifikasi produk diatur dibawah kerjasama antara Jet Propulsion Laboratory (JPL) dan University of Texas Center for Space Research (UTCSR), serta GeoForschungsZentrum Postdam (GFZ). Data gaya berat oleh satelit GRACE disediakan dalam bentuk spherical harmonic coefficients (GRACE level 2 data). Data tersebut diolah oleh CSR dan dikelola oleh JPL dan GFZ.

Sementara data water thickness berasal dari data gaya berat hasil pengamatan oleh satelit GRACE dalam bentuk koefisien spherical harmonic (dengan invers modelling methode) yang diproses oleh D. P. Chambers. Data ini telah direduksi dengan harga rata-rata dari data seluruh pengamatan untuk menghindari aliasing effect dari sirkulasi atmosfer dan laut. Water thickness adalah jumlah distribusi massa air pada daratan, meliputi semua peristiwa dalam siklus hidrologi seperti presipitasi, evapotranspirasi, aliran air, snow coverage, soil moiture dan groundwater storage (Anjasmara, 2006). Dan water thickness residual adalah besarnya nilai perubahan water thickness.

Data water thickness selama beberapa bulan dari pengamatan satelit GRACE dapat digunakan untuk menginvestigasi perubahan kandungan air dalam waktu itu. Dari data yang telah diolah, dapat ditunjukkan distribusi massa air yang mengalami perubahan dari bulan ke bulan. Dari sini juga dapat dilihat dimana saja lokasi di bumi ini yang memiliki banyak atau sedikit air (Anjasmara, 2006).

\section{Medan Gaya Berat Bumi (Gravity Field of The Earth)}

Gaya gravitasi adalah gaya atau kekuatan tarikan Bumi pada suatu benda (Heiskanen dan Moritz, 1967). Newton mendefinisikan bahwa tarikan dari gaya gravitasi merupakan suatu fungsi dari massa dan jarak. Hukum Newton kesatu ini pada dasarnya menyatakan hubungan antara gaya dan gerak yang menempatkan keduanya sebagai suatu hubungan sebab-akibat.

$$
F=k \frac{M_{1} M_{2}}{l^{2}}
$$

Dimana,

$M_{1}=$ massa benda 1 ,

$M_{2}=$ massa benda 2,

$l=$ jarak antara benda 1 dan benda 2 .

Gaya adalah penyebab perubahan besar kecepatan (laju) dan arah gerak (arah kecepatan) benda. Hukum Newton kedua menyatakan besarnya perubahan gerak benda yang secara pengukuran disebut percepatan 
berbanding terbalik dengan massa benda itu dan berbanding lurus dengan gaya penyebabnya.

$$
\frac{F}{M 1}=g=k \frac{M e}{l^{2}}
$$

Dimana,

$g=$ percepatan gravitasi bumi,

$M e=$ massa bumi,

$l=$ jari-jari bumi,

$k=$ konst. grafitasi $6.67259 \times 10^{-8} \mathrm{~cm}^{3} \mathrm{~g}^{-1} \mathrm{~s}^{-2}$.

Total gaya, yaitu resultan gaya gravitasi dan gaya sentrifugal disebut dengan gaya berat (gravity). Potensial gaya berat $W$ merupakan jumlah dari potensial gaya gravitasi $V$ dan gaya sentrifugal $\Phi$ (Heiskanen dan Moritz, 1967).

$$
\begin{aligned}
W(x, y, z) & =V+\Phi \\
= & k \iiint_{v} \frac{\rho}{l} d v+\frac{1}{2} \omega^{2}\left(x^{2}+y^{2}\right)
\end{aligned}
$$

Dimana,

$\rho=$ densitas,

$d v=$ elemen dari volume,

$\omega=$ kecepatan angular rotasi bumi.

\section{Time Variable Gravity}

Time-variable gravity merupakan medan gaya berat yang berubah terhadap waktu. Terjadi karena suatu fenomena yang kompleks seperti distribusi continent dan ocean water storage, pasang surut air laut, perubahan atmosfer, pencairan es di kutub, variasi groundwater storage dan es, bencana alam, aktifitas arus konveksi dan inti bumi, serta fenomena geofisik lainnya yang menyebabkan gaya berat berubah (Sideris, 2002). Nilai gayaberat selalu berubah, demikian pula halnya dengan geoid, sehingga sangatlah penting untuk memahami variasi ini karena sangat berguna untuk memonitor iklim global dan proses geofisik, rotasi bumi, dan perubahan tinggi muka air laut.

\section{Static Gravity}

Static gravity merupakan medan gaya berat yang dinyatakan dalam keadaan tetap. Terjadi karena distribusi massa yang hanya bervariasi pada skala waktu yang berdasarkan kondisi geologi, seperti daratan, pegunungan, tekanan pada kerak bumi, dan sebagainya (Schwarz, 2001). Static gravity didominasi oleh ketidakteraturan bumi yang disebabkan oleh proses konveksi yang membentuk bumi dalam skala waktu ratusan hingga jutaan tahun. Pada berbagai aplikasi diperlukan informasi geoid statik, yaitu yang tidak berubah terhadap waktu. Geoid yang demikian diturunkan juga dari data gaya berat statik. Pengertian statik dalam hal ini adalah setelah komponen time varying dari data gaya berat dihilangkan.

\section{Distribusi Massa Air di Bumi}

Bumi merupakan sistem dinamik yang kompleks yang mencakup permukaan zat cair/ surface fluid (atmosfer, laut, darat, dan es), mantel dan inti bumi yang berinteraksi dalam variasi temporal dan spasial (Gross, 2006). Dalam skala waktu, distribusi massa terutama terjadi dalam permukaan zat cair dan berhubungan dengan variasi iklim. Permukaan zat cair berinteraksi satu sama lain, menghasilkan variasi cuaca dan fenomena geofisik lain. Selain itu, interaksi antara bumi dan seluruh komponen dan permukaan zat cairnya juga menimbulkan variasi bentuk.

Distribusi massa di seluruh permukaan bumi berubah-ubah dalam variasi waktu, namun massa bumi adalah tetap, yaitu sekitar $6 \times 10^{24}$ $\mathrm{kg}$. Istilah massa dapat didefinisikan dengan sejumlah substansi yang secara langsung berhubungan dengan densitas dari massa tersebut, dapat berupa air, es dan sebagainya (Davis, 2002). 


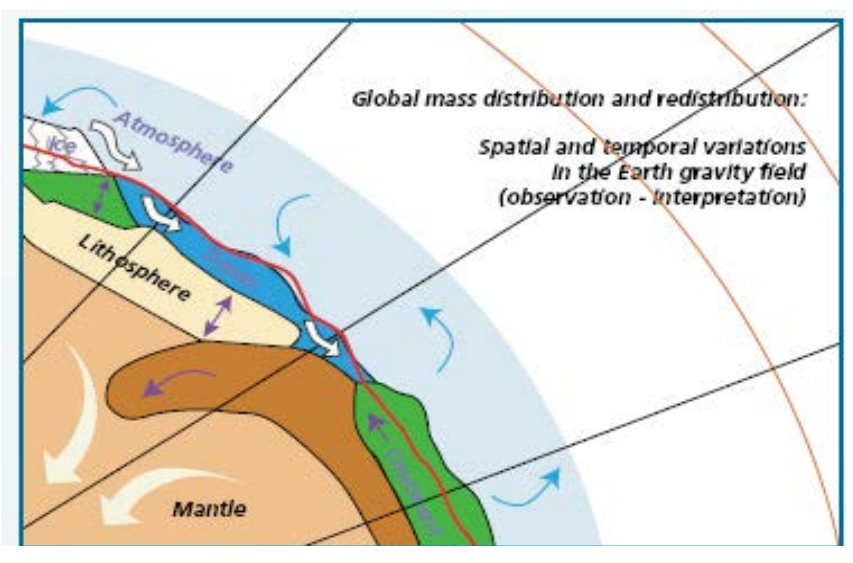

Gambar 3. Distribusi dan redistribusi massa di bumi (http://www.damtp.cam.ac.uk/user/jmr64/ cphII_final_revised.pdf)

Dalam periode yang cukup lama ini, perubahan massa di bumi dihubungkan dengan pergerakan massa air, mengingat air merupakan komponen terbesar di bumi. Distribusi massa air dapat digambarkan dalam suatu siklus yang disebut dengan siklus hidologi, yaitu suatu proses perubahan wujud air yang terjadi di alam secara terus- menerus.

Distribusi massa air terjadi di darat dan di laut. Di darat distribusi tersebut terjadi dalam bervariasi skala waktu. Untuk skala waktu pendek/musiman meliputi presipitasi, evapotranspirasi dan aliran air (runoff), dengan penyimpanan air pada danau, tanah, vegetasi dan sebagainya. Untuk skala waktu yang panjang meliputi penyimpaan air pada es dan gletser. Di laut distribusi massa air terutama disebabkan oleh pasang surut air laut, tekanan angin laut, tekanan panas air laut, arus laut dan sebagainya (Chao et al., 2000).

\section{Hubungan Antara GRACE, Gaya Berat, Distribusi Massa Air, dan Water Thickness}

GRACE merupakan suatu satelit pengukur variasi medan gaya berat bumi, melalui pengamatan bagaimana variasi massa bumi dari tempat satu ke tempat lain pada permukaan bumi. Satelit ini memonitor perubahan gaya berat yang disebabkan oleh pergerakan air di darat, laut, es dan atmosfer. Gaya berat secara tidak langsung dapat ditentukan oleh bagaimana material pembentuk bumi didistribusikan.

Seperti yang telah diketahui bahwa massa dan gaya berat berkorelasi, peningkatan massa berhubungan dengan peningkatan gaya berat (Anjasmara, 2006).

$$
M=\rho \times v
$$

Dimana,

$M=$ massa,

$\rho=$ densitas,

$v=$ volume.

Karena massa dan densitas berhubungan, maka secara langsung akan ada hubungan antara densitas dan gaya berat. Peningkatan pada densitas adalah peningkatan pada massa, dan peningkatan massa adalah peningkatan gaya berat.

Secara matematis hubungan dari potensial gaya berat dan massa diberikan oleh persamaan berikut ini (Heiskanen dan Moritz, 1967):

$\boldsymbol{V}=k \iiint_{\text {earth }} \frac{d M}{l}=k \iiint_{\text {earth }} \frac{\rho d v}{l}$

Dimana,

$V=$ potensial gaya berat bumi,

$d M=$ elemen massa yang membentuk bumi,

$k=$ konst. grafitasi $\left(6.67259 \times 10^{-8} \mathrm{~cm}^{3} \mathrm{~g}^{-1} \mathrm{~s}^{-2}\right)$,

$l=$ jari-jari bumi,

$d v=$ elemen dari volume, dan

$\rho=$ densitas.

Jika fungsi densitas $\rho$ dalam hal ini tidak diketahui, maka penyelesaian dengan formula (5) tidak dapat digunakan. Dengan demikian, dapat dinyatakan dengan spherical harmonic series yang lebih kompleks sebagai solusinya (disebut direct problem). 
$V(\varphi, \lambda, r)=\frac{k}{r}+\frac{k}{r} \sum_{l=2}^{N \max }\left(\frac{R}{r}\right)^{l} \sum_{m=0}^{l} p_{l m}(\sin \varphi)\left\{\hat{C_{l m}}(t) \cos \lambda \lambda+\overline{S_{l m}}(t) \sin m \lambda\right\}$

$\left\{\frac{\overline{C_{l m}}}{S_{l m}}\right\}=\frac{1}{2 l+1) M e} x \iiint_{\text {Global }}\left(\frac{r}{R}\right)^{l} \bar{P}_{l m}(\sin \varphi)\left\{\begin{array}{c}\cos m \lambda \\ \sin m \lambda\end{array}\right\} d M$

Sedangkan variasi potensial diberikan dengan formula sebagai berikut

$$
\Delta V(\varphi, \lambda, r)=\frac{k}{r} \sum_{l=2}^{N \max } \sum_{m=0}^{l} \overline{p_{l m}}(\sin \varphi)\left\{\overline{C_{l m}}(t) \cos m \lambda+\overline{S_{l m}}(t) \sin m \lambda\right\}
$$

Dimana,

$V=$ potensial gaya berat,

$r=$ geocentrics radius,

$R=$ mean equatorial radius,

$\overline{p_{l m}}=$ Associated Legendre Polynomial

derajat $l$ dan orde $m, \overline{C_{l m}}, \overline{S_{l m}}=$ koefisien

fully normalized spherical harmonic.

Formula untuk Associated Legendre

Polynomial dituliskan oleh Torge (1980) sebagai berikut :

$$
\begin{gathered}
p_{l m}=\mathbf{N}_{\mathbf{l m} .} \mathbf{P}_{\mathbf{l m}} \\
\mathrm{N}_{\mathrm{lm}}{ }^{2}=\frac{k(2 l+1)(l-m) !}{(l+m) !} \\
k=\left\{\begin{array}{l}
1 \text { untuk } \mathrm{m}=0 \\
2 \text { untuk } \mathrm{m} \neq 0
\end{array}\right. \\
\mathrm{P}_{\operatorname{lm}}(\mathrm{u})=\left(1-u^{2}\right)^{\frac{m}{2}} \frac{d^{m}}{d u^{m}} P_{l}(u) \\
\mathrm{P}_{1}(\mathrm{u})=\frac{1}{2^{n} x l !} \times \frac{d^{l}}{d u^{l}}\left(u^{2}-1\right)^{l}
\end{gathered}
$$

Dimana,

$u=\cos \psi$,

$\psi=$ sudut pusat antara dua arah.

Formula untuk koefisien fully normalized spherical harmonic adalah (Földvary dan Fukuda, 2002)

Dengan $M e$ adalah massa bumi.

Penyelesaian tersebut dikenal dengan Direct problem (Heiskanen dan Morizt, 1967), yaitu suatu proses penentuan medan gaya berat dari massa.

Hubungan yang lain dapat dinyatakan dengan Inverse problem yang digunakan untuk menentukan distribusi massa dari medan gaya berat. Jika diasumsikan bahwa variasi potensial disebabkan oleh perubahan massa permukaan (surface mass), maka variasi massa dapat secara langsung ditentukan dari $\overline{C_{l m}}$ dan $\overline{S_{l m}}$ (Anjasmara, 2006):

$$
\begin{aligned}
& \Delta \sigma(\varphi, \lambda, \mathrm{t})=\frac{R \rho_{\text {ave }}}{3} \sum_{l=2}^{N \max } \sum_{m=0}^{n}\left(\frac{2 n+1}{n+k_{l}}\right)^{l} \overline{P_{n m}}(\sin \varphi) \\
& \left\{\overline{C_{l m}}(t) \cos m \lambda+\overline{S_{l m}}(t) \sin m \lambda\right\}
\end{aligned}
$$

Dimana,

$\Delta \sigma=$ surface mass (mass/area),

$\rho_{\text {ave }}=$ densitas rata-rata bumi $\left(5517 \mathrm{~kg} / \mathrm{m}^{3}\right)$,

$k_{l}=$ love numbers.

Redistribusi massa pada dan di bawah permukaan bumi terjadi secara dinamik setiap waktu, maka medan gaya berat bumi juga berubah setiap waktu. Medan gaya berat bumi menyatakan komposisi dan struktur bumi, meliputi distribusi atmosfer dan massa air pada dan di bawah permukaan bumi. Dalam periode ratusan tahun ini, distribusi massa bumi terutama dipengaruhi oleh distribusi air. Perubahan gaya berat dalam hal ini dibentuk dalam perubahan water thickness (Anjasmara, 2006). Perubahan water thickness diperoleh dari membagi variasi massa $\Delta \sigma$ dengan densitas air $\rho_{\text {water }}\left(1000 \mathrm{~kg} / \mathrm{m}^{3}\right)$. 


\section{Variasi dan Perubahan Iklim}

Iklim merupakan keadaan rata-rata cuaca suatu wilayah yang relatif luas dalam waktu yang lama. Selain dengan memperhatikan unsurunsur cuaca, iklim ditentukan pula oleh letak lintang, letak geografis, arus laut, letak relief, dan angin global (Winardi dkk, 2004).

Iklim di dunia selalu berubah, baik menurut ruang maupun waktu. Perubahan iklim ini dapat dibedakan berdasarkan wilayahnya (ruang), yaitu perubahan iklim secara lokal dan global. Berdasarkan waktu, iklim dapat berubah dalam bentuk siklus, baik harian, musiman, tahunan, maupun puluhan tahun. Perubahan iklim adalah perubahan unsur-unsur iklim yang mempunyai kecenderungan naik atau turun secara nyata.

Pada skala waktu tertentu, distribusi massa terjadi di dalam permukaan zat cair/ surface fluid (atmosfer, laut, darat, es) dan berhubungan dengan variasi iklim. Dimana sistem iklim merupakan suatu sistem antara air dan siklus energi di bumi. Air adalah komponen terpenting dan terbesar yang mempengaruhi cuaca dan iklim, mengingat komposisi air adalah $70 \%$ dari seluruh komponen di bumi (NASA Oceanography, 2005). Air mempengaruhi iklim melalui penyerapan panas yang dibebaskan radiasi matahari yang dibutuhkan untuk mengendalikan sirkulasi atmosfer, melalui pancaran aerosol yang mempengaruhi tutupan awan, melalui emisi sebagian besar air yang turun ke bumi sebagai hujan, melalui penyerapan karbon dioksida dari atmosfer dan penyimpanannya untuk beberapa juta tahun. Air menyerap banyak energi matahari yang diperoleh bumi, dan memberikan panas, serta dapat membebaskan panas secara perlahan dalam beberapa bulan atau tahun. Iklim dipengaruhi oleh kandungan panas dan karbon diosida. Variasi serta perubahan iklim dapat diamati secara tidak langsung melalui pengamatan distribusi massa air di bumi (Anjasmara, 2008).

\section{Metode Grid Delaunay Trianguation with Linear Interpolation}

Metode grid (gridding) menetukan prosedur interpolasi dari pembuatan file grid. Setiap metode grid menghasilkan perhitungan grid yang berbeda-beda (Budiyanto, 2005).

Metode ini bermanfaat untuk menghasilkan analisis patahan. Analisis ini dapat dihasilkan dari metode ini dengan data yang cukup dan menyebar secara merata. Data ini membutuhkan data yang banyak. Pada jumlah data yang sedikit, metode ini tidak efektif. Sedangkan dengan data yang banyak, yaitu lebih dari 1000 titik pengukuran, dapat bekerja dengan sangat cepat dan memberikan hasil yang baik (Budiyanto, 2005).

\section{PENGOLAHAN DATA}

\section{Data Penelitian berupa :}

1. Data Water Thickness Ocean dari pengolahan data gaya berat satelit GRACE untuk wilayah seluruh dunia dalam format ASCII selama 33 bulan (Februari 2003 hingga April 206, kecuali Januari dan Juni 2003, Januari 2004, serta Juli-Oktober 2004).

2. Data Water Thickness Land water dari pengolahan data gaya berat satelit GRACE untuk wilayah seluruh dunia dalam format ASCII selama 33 bulan (Februari 2003 hingga April 206, kecuali Januari dan Juni 2003, Januari 2004, serta Juli-Oktober 2004).

3. Data pendukung lainnya, yaitu Peta Presipitasi dunia dari GPCC (Global Precipitation Climatology Centre). 


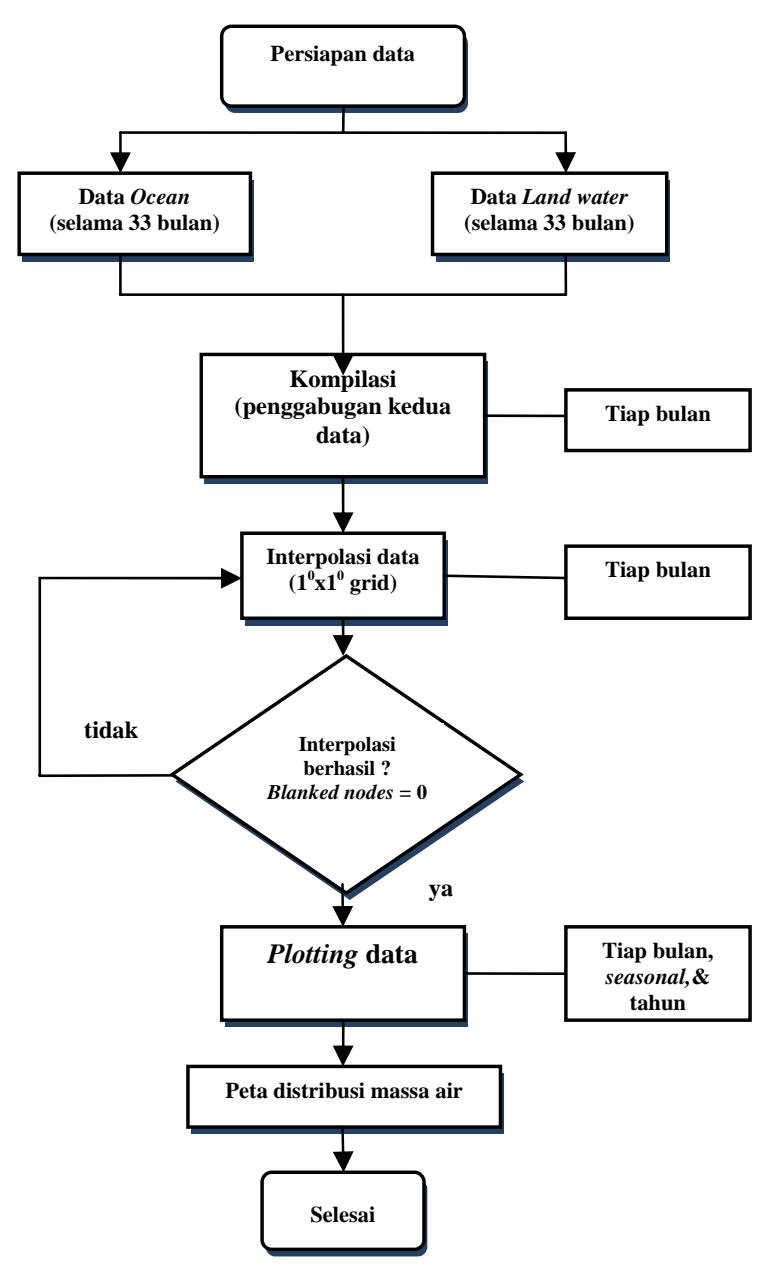

Gambar.4 Diagram Alir Pengolahan Data

\section{HASIL DAN DISKUSI}

Hasil yang diperoleh dari plotting data selama 33 bulan berupa peta perubahan water thickness bulanan dan seasonal yang dapat digunakan untuk mengamati perubahan dan perbedaan kandungan air. Hasil plotting perubahan water thickness menunjukkan variasi distribusi massa air global yang tinggi pada beberapa daratan di dunia. Diantara daratan tersebut adalah wilayah-wilayah tropis seperti Amerika Selatan, Afrika, dan Asia Selatan, serta wilayah pada high latitudes yaitu Amerika Utara, Eropa Timur dan Eropa Utara. Dari sini dapat dilihat bahwa selama itu ada yang memiliki banyak air dan yang memiliki sedikit air.
Variasi distribusi massa air yang tinggi pada wilayah Amerika Selatan, Afrika, dan Asia Selatan, Amerika Utara, Eropa Timur dan Eropa Utara tersebut disebabkan karena adanya variasi iklim dan faktor-faktor lain yang turut mengendalikan terjadinya variasi tersebut seperti presipitasi, hutan hujan topis yang besar dan aliran sungai besar beserta basinnya yang mendistribusikan massa air dari tempat satu ke tempat yang lain dan akan mempengaruhi kandungan air pada wilayah tertentu. Namun beberapa daerah distribusi airnya tidak dihubungkan oleh hutan hujan tropis seperti Eropa Utara, Eropa Timur dan Amerika Utara, yang cenderung dipengaruhi oleh es dan salju yang menutupi daratan pada saat musim dingin dan mencair pada musim panas.

Variasi ini akan mempengaruhi distribusi massa air dalam fungsi besaran, sebaran, dan waktu di seluruh wilayah di dunia, tak terkecuali wilayah Indonesia.

Sementara untuk wilayah laut, distribusi massa airnya dihubungkan dengan peristiwa aliran air dari darat ke laut, evaporasi dan presipitasi serta sirkulasi air laut lain seperti pasang surut, tekanan panas, angin laut, arus laut dan sebagainya. Variasi distribusi massa airnya sulit untuk diinterpretasikan karena pada dasarnya wilayah lautan selama ini selalu terdiri dari air dan perubahannya tidak begitu tampak seperti di darat. Sehingga jika diamati pada hasil plotting, perubahan water thickness adalah relatif kecil.

Pada data perubahan water thickness dari Februari 2003 hingga April 2006, kecuali Juni 2003, Januari 2004, dan Juli-Oktober 2004 tersebut dapat dilihat trend perubahan water thickness yang menunjukkan trend distribusi massa air. Data tersebut juga menunjukkan wilayah yang memiliki banyak dan sedikit air selama waktu itu. Gambar 5 menunjukkan trend distribusi massa air. 

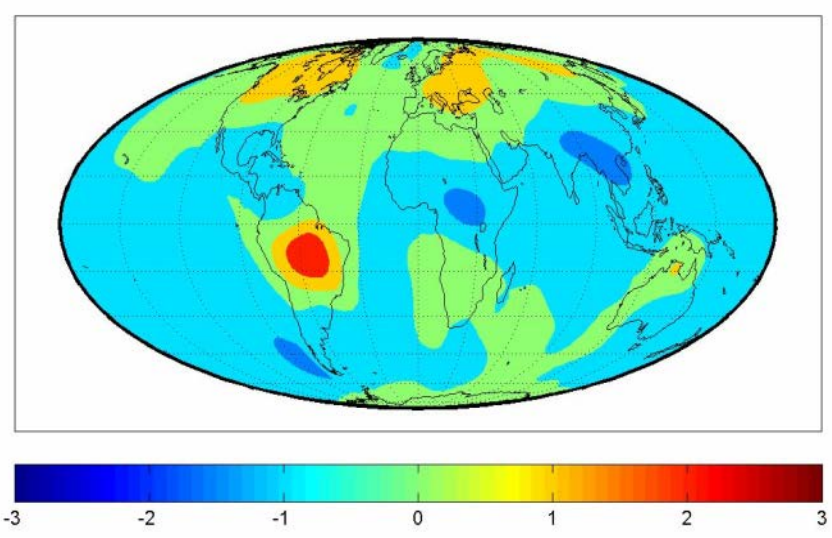

Gambar 5 Trend Distribusi Massa Air
(dalam cm/tahun)

Hasil plotting menunjukkan bahwa pola distribusi massa air tidak mengalami perubahan yang sangat signifikan dari tahun ke tahun dari Februari 2003 hingga April 2006, kecuali Juni 2003, Januari 2004, dan JuliOktober 2004. Sehingga secara tidak langsung, melalui pengamatan distribusi massa air global ini, dapat dikatakan bahwa tidak ada gangguan-gangguan alam yang sangat mempengaruhi terjadinya perubahan pola distribusi massa air global selama itu, terkait dengan iklim.

Dari hasil plotting dan grafik juga dapat dilihat adanya pebedaan massa air. Dimana ketika suatu wilayah memiliki massa air yang tinggi, maka ada wilayah lain yang memiliki massa air yang rendah. Sebagai contoh yang jelas sekali adalah wilayah Amerika selatan dan Asia selatan. Ketika wilayah Amerika selatan memiliki jumlah air yang banyak, wilayah Asia selatan memiliki jumlah air yang sedikit.

Variasi distribusi massa air akan mengakibatkan adanya perbedaan kandungan air dalam fungsi besaran, sebaran, dan waktu di wilayah-wilayah tertentu, dimana akan terdapat wilayah yang memiliki kandungan air yang sangat banyak dan wilayah dengan kandungan air yang sangat sedikit. Dan besarnya kandungan air ini akan mempengaruhi pula variasi medan gaya berat bumi. Gaya berat berbanding lurus dengan massa, yang berarti apabila ada peningkatan massa maka gaya berat juga akan meningkat.

\section{DAFTAR PUSTAKA}

Andreas, H., 2006. Satelit Gravimetry, <URL : http://geodesy.gd.itb.ac.id/?page id=501 . Dikunjungi pada tanggal 30 Oktober 2006, jam 17.36.

Anjasmara, I.M., 2006. Temporal Variability of the Earth's Gravity Field Observed by GRACE. Surveying/Mapping Project 690. Postgraduate Diploma.

Away, Gunaidi Abdia. 2006. The Shortcut of Matrix Laboratory (MATLAB). Informatika. Bandung.

Butler, Rhett. 2006. Hutan Hujan, <URL : http://world.mongabay.com/indonesian/i ndonesian.pdf. Dikunjungi pada tanggal 9 Mei 2007, jam 19.50.

Budiyanto, Eko. 2005. Pemetaan Kontur dan Pemodelan Spasial 3 Dimensi Menggunakan Surfer. Andi. Yogyakarta.

Chao, B.F., Dehant, V., Gross, R.S., Ray, R.D., Salstein, D.A., Watkins, M.M., dan Wilson, C.R. 2000. Space Geodesy Monitors Mass Transports in Global Geophysical Fluids, <URL :

http://bowie.gsfc.nasa.gov/ggfc/EOS art icle.pdf. Dikunjungi 7 Februari 2007, jam 11.43.

Davis, Ab., 2002. GRACE Mission, <URL : http://www.damtp.cam.ac.uk/user/jmr64/ cphII final revised.pdf. Dikunjungi pada tanggal 29 Januari 2007, jam 11.42.

GFZ Postdam. Sept. 2006.The GRACE Mission, <URL: http://www.gfzpostdam.de/pbl/op/grace/. Dikunjungi pada tanggal 15 November 2006, jam 05.02. 
Gross, R.S., 2006. Mass Transport and Dynamics in the Earth System : The Unsolved Scientific Question and Observational Requirements, $<\mathrm{URL}$ : http://geodesy.unr.edu/ggos/ggosws 200 6/position papers/Gross Position Paper. pdf. Dikunjungi pada tanggal 7 Februari 2007, jam 11.36.

Heiskanen, W. A. Dan Moritz, H. (1967) Physical Geodesy, W.H. Freeman and Company, San Francisco.

IGOS. Nov. 2003. A global Cycle for the IGOS Partnership, < URL : http://www.igos/vers.1.05/2003/global cycle.doc. Dikunjungi pada tanggal 19 Januari 2007, jam 07.30.

JPL. 2006. Monthly Mass Grids, <URL : http://gracetellus.jpl.nasa.gov/month ma ss.html. Dikunjungi pada tanggal 15 November 2006, jam 04.33.

NASA Report, Grace Brochure, <URL: http://www.csr.utexas.edu/grace/publicat ions/brochure/GRACE Brochure.pdf. Dikunjungi pada tanggal 29 Januari 2007, jam 11.16.

NASA Report. Feb. 2004. GRACE Gravity Measurement, <URL:http://www.csr.ute xas.edu/grace/science/gravitymeasurem ent.html. Dikunjungi pada tanggal 18 November 2006, jam 03.32.

NASA Report, GRACE Launch Press Kit, $<$ URL:

http://www.jpl.nasa.gov/news/press kits/ gracelaunch.pdf. Dikunjungi pada tanggal 31 Januari 2007, jam 19.53.

Noname. Where Are The Rainforests, <URL: http://www.srl.caltech.edu/personnel/kru bal/rainforest/Edit560s6/www/where.ht $\underline{\mathrm{ml}}$. Dikunjungi pada tanggal 26 September 2007, jam 08.54.
Perlman, Howard. 2007. The water cycle, $<\mathrm{URL}$

http://ga.water.usgs.gov/edu/watercycle malay.html. Dikunjungi pada tanggal 7 Mei 2007, jam 20.48.

Rusydi, Febdian. 2007. Salju, Fenomena Alam yang Menakjubkan : Cintaku Sehangat Salju, $<\quad$ URL

http://www.kimianet.lipi.go.id.

Dikunjungi pada tanggal 7 Mei 2007, jam 20.28.

Schmidt, R., dan Schwintzer, P., 2006. GRACE observations of changes in continental water storage, $<\mathrm{URL}: \underline{\mathrm{http}: / \text { www.geo.unifrankfr }}$ ut.de/fb/fb11/jpg/ag/dl/fpublikationen/20 06/schmidental2006 GRACE.pdf. Dikunjungi pada tanggal 31 Januari 2007, jam 20.07.

Schwarz, K.P., 1997. Geodesy on the Move. Springer. Rio de Jaeneiro. Brazil.

Sideris, M. G. 2002. Gravity, Geoid and Geodynamics 2000. Springer. Verlag Berlin Heidenberg.

Smith, A.B., Walker, J.P., dan Western, A.W., 2004. Assimilation of gravity data into a soil moisture and groundwater column model, <URL:http://www.civenv.unimelb.edu.a u/ jwalker/papers/cahmda04-1.pdf. Dikunjungi pada tanggal 31 Januari 2007, jam 20.26.

Swenson, S.C., dan Milly, P. C. D., 2006. Climate model biases in seasonality of continental water storage revealed by satellite gravimetry, $<\mathrm{URL}$ : http://www.gfdl.noaa.gov/reference/bibli ography/2006/scs0601.pdf. Dikunjungi pada tanggal 5 Januari 2008, jam 18.26. 
Torge, Wolfgang. 1980. Geodesy. Walter de Gruyter. Berlin. New York.

Winardi, dkk. 2004. Geografi. Piranti Darma Kalokatama. Jakarta.

\section{LAMPIRAN}

\section{Contoh Hasil Plotting Monthly Water Thickness Changes}

\section{Februari 2003 (dalam cm)}

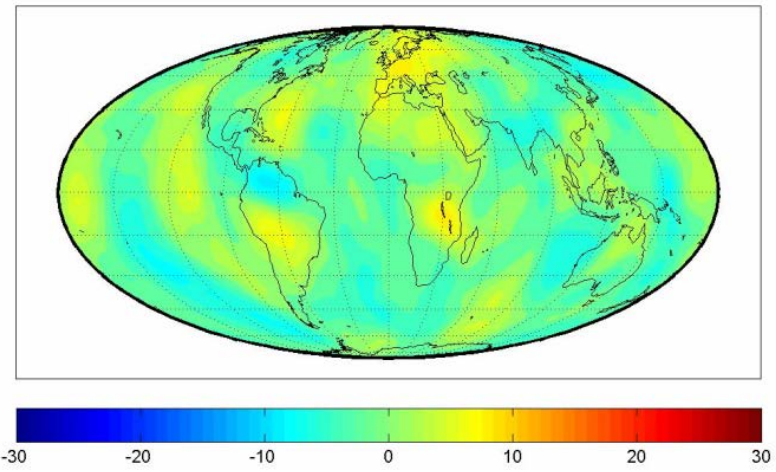

\section{April 2003 (dalam cm)}

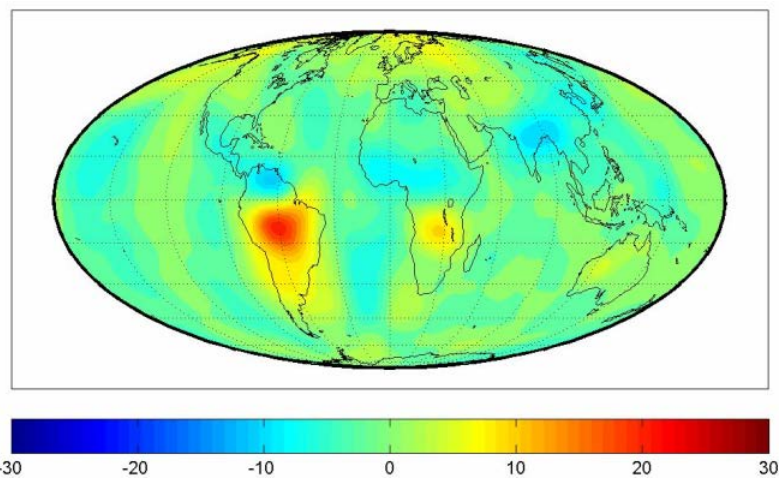

Juli 2003 (dalam cm)

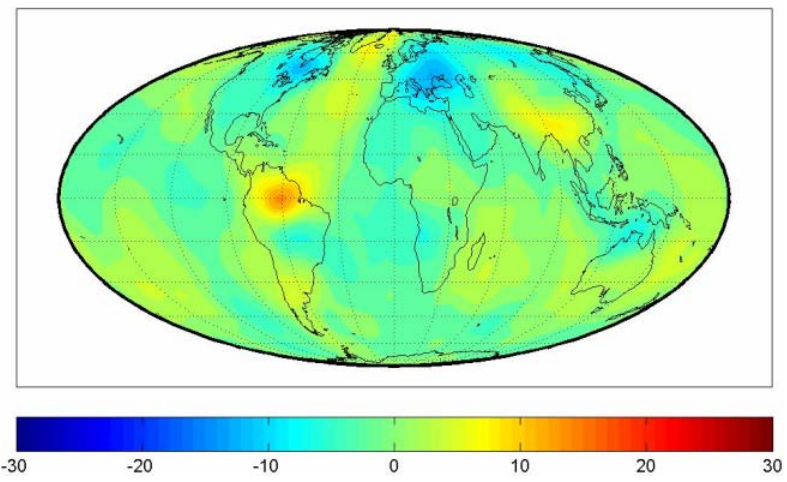

September 2003 (dalam cm)

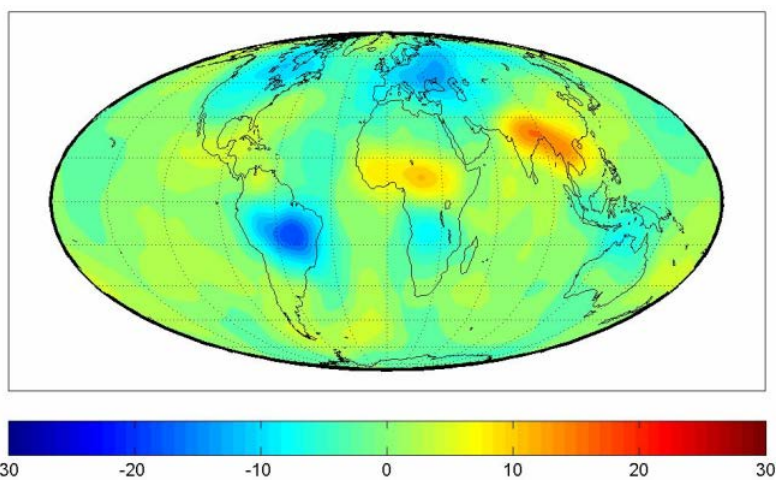

November 2003 (dalam cm)

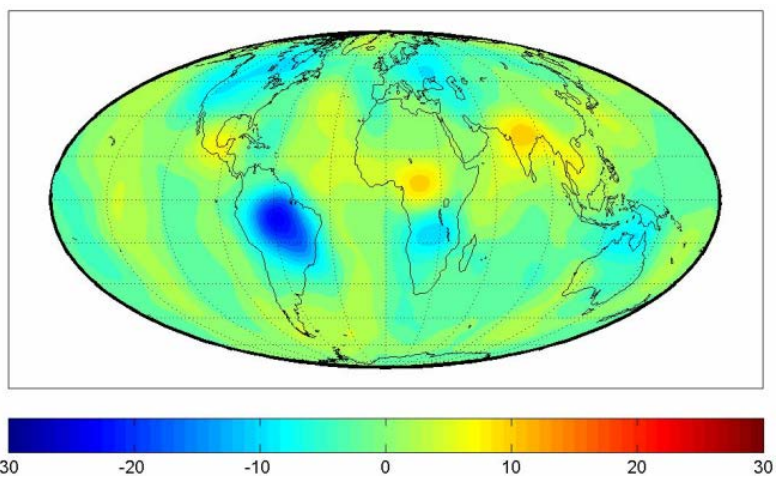

Februari 2004 (dalam cm)

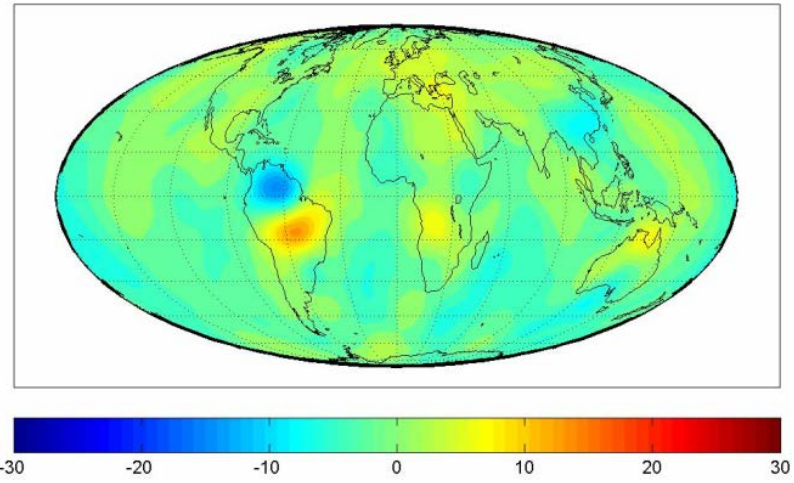




\section{LAMPIRAN}

Contoh Peta Monthly Precipitation dari Global Precipitation Climatology Center (GPCC)

\section{Februari 2003}

GPCC Monitoring Product Gauge-Bosed Anolysis 1.0 degree

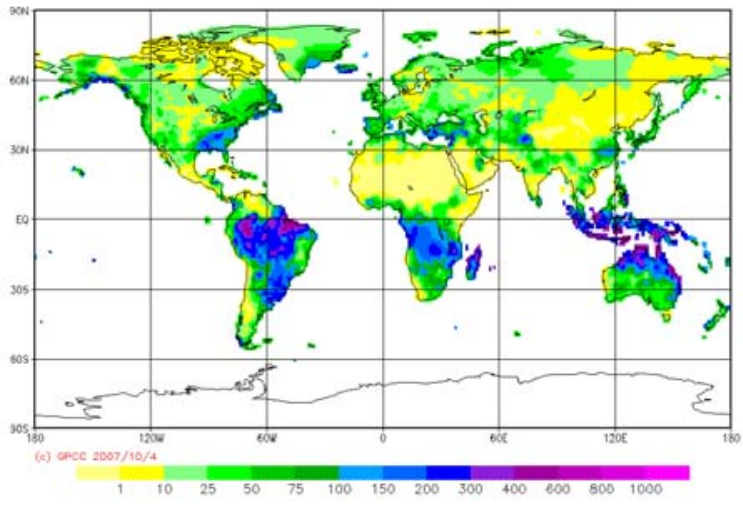

April 2003

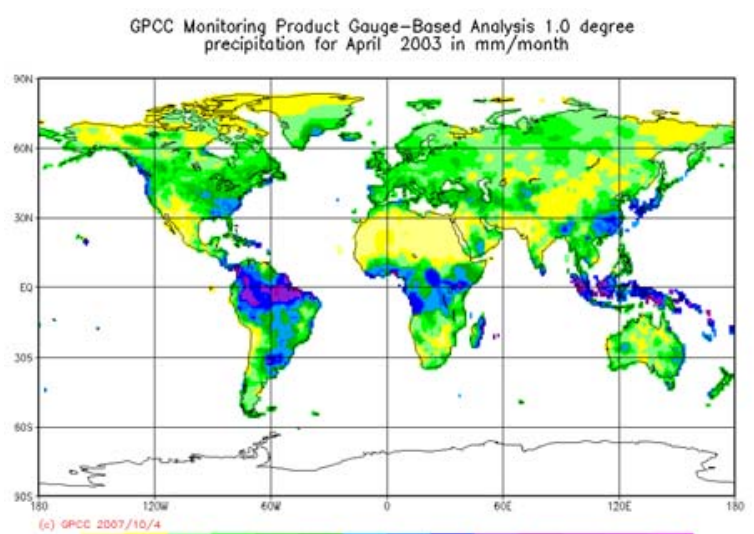

Juli 2007

GPCC Monitoring Product Gauge-Bosed Anolysis 1.0 degree
precipitation for July 2003 in mm/month

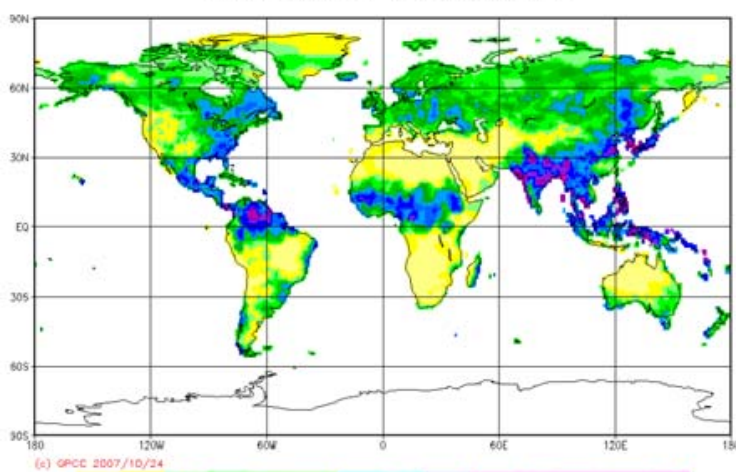

\section{September 2003}

GPCC Monitoring Product Gauge-Bosed Anolysis 1.0 degree

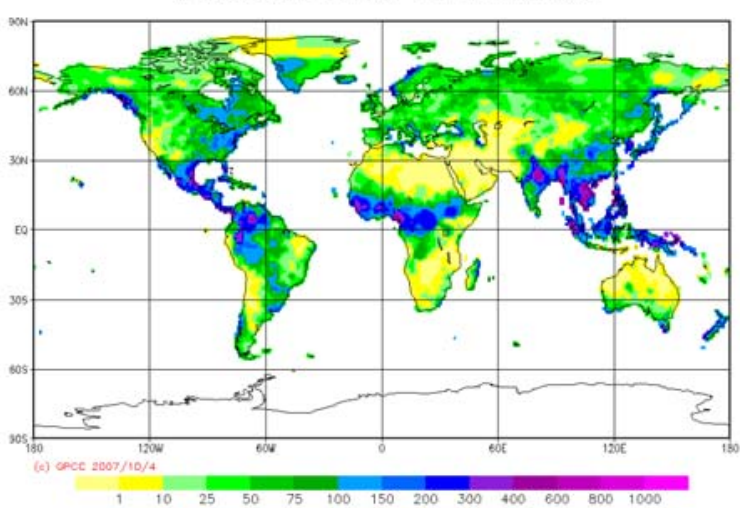

November 2003

GPCC Monitoring Product Gauge-Bosed Anolysis 1.0 degree precipitation for November 2003 in mm/month -

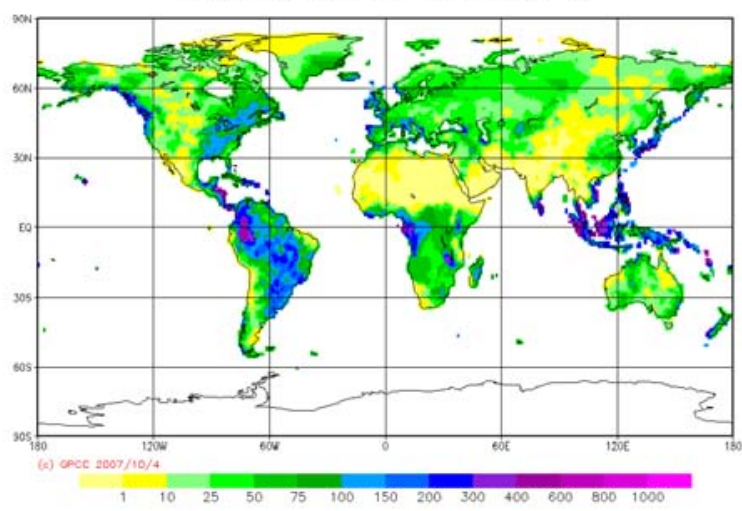

Februari 2004

GPCC Monitoring Product Gauge-Bosed Anolysis 1.0 degree Monitoring Product Gouge-Bosed Anolysis 1.0 degree
precipitation for Februory 2004 in $\mathrm{mm} / \mathrm{month}$

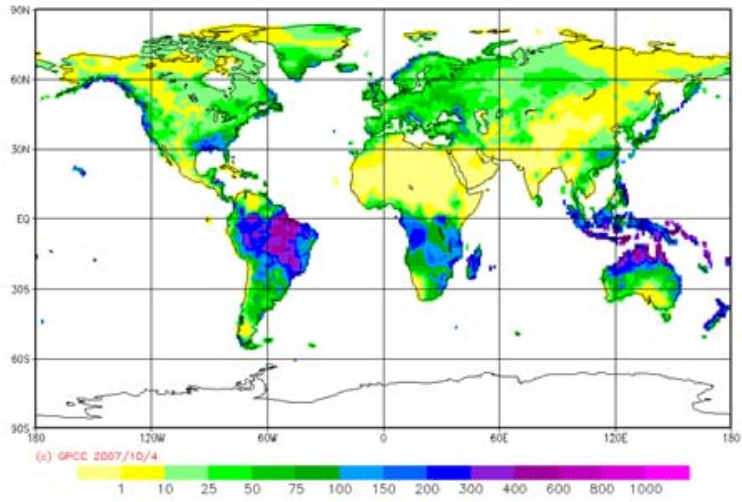

